\section{HARMONI SOSIAL}

Jurnal Pendidikan IPS
Harmoni Sosial: Jurnal Pendidikan IPS

Volume 3, No 2, September 2016 (188-198)

Online: http://journal.uny.ac.id/index.php/hsjpi

\title{
PENGARUH KOMPETENSI GURU, MOTIVASI BELAJAR, DAN LINGKUNGAN KELUARGA TERHADAP HASIL BELAJAR MATA PELAJARAN EKONOMI
}

\author{
Sutardi, Sugiharsono \\ Program Studi Pendidikan Ekonomi, Universitas Negeri Yogyakarta \\ sutardi190@gmail.com, sugiharsono@uny.ac.id
}

\begin{abstract}
Abstrak
Penelitian ini bertujuan untuk mengetahui pengaruh kompetensi guru, motivasi belajar, dan lingkungan keluarga terhadap hasil belajar siswa. Penelitian ini merupakan penelitian asosiatif kausal dengan pendekatan kuantitatif. Populasi penelitian ini adalah semua siswa kelas XI IPS di 45 SMA negeri dan swasta di Kota Yogyakarta. Sampel siswa sebanyak 122 siswa ditentukan dengan teknik area proporsional random sampling. Pengumpulan data menggunakan angket untuk variabel kompetensi guru, motivasi belajar, dan lingkungan keluarga, serta dokumentasi untuk variabel hasil belajar. Pengujian validitas instrumen dilakukan dengan expert judgment dan analisis factor, sedangkan uji reliabilitas menggunakan Alfa Cronbach. Hasil penelitian menunjukkan bahwa: (1) kompetensi guru berpengaruh positif dan signifikan terhadap hasil belajar siswa dengan kontribusi efektif $\left(\mathrm{R}^{2}\right)$ sebesar 7,8\%; (2) motivasi belajar berpengaruh positif dan signifikan terhadap hasil belajar siswa dengan kontribusi efektif $\left(\mathrm{R}^{2}\right)$ sebesar $36,8 \%$, (3) lingkungan keluarga berpengaruh positif dan signifikan terhadap hasil belajar siswa dengan kontribusi efektif $\left(\mathrm{R}^{2}\right)$ sebesar 4,1\%; (4) kompetensi guru, motivasi belajar, dan lingkungan keluarga secara bersama-sama berpengaruh positif dan signifikan terhadap hasil belajar siswa dengan kontribusi efektif $\left(\mathrm{R}^{2}\right)$ sebesar $43,1 \%$. Hal ini berarti variabel kompetensi guru, motivasi belajar, dan lingkungan keluarga mempengaruhi variabel hasil belajar siswa secara terpisah maupun secara bersama-sama.
\end{abstract}

Kata Kunci: kompetensi guru, motivasi belajar, lingkungan keluarga, hasil belajar

\section{THE EFFECTS OF TEACHER COMPETENCY, LEARNING MOTIVATION, AND HOME ENVIRONMENT ON STUDENTS' ACHIEVEMENT IN ECONOMICS IN SMA'S}

\author{
Sutardi, Sugiharsono \\ Program Studi Pendidikan Ekonomi, Universitas Negeri Yogyakarta \\ sutardi190@gmail.com, sugiharsono@uny.ac.id
}

\begin{abstract}
This study aims to reveal the effects of teacher competency, learning motivation, and home environment on students' learning achievement. This study was associative research employing quantitative data. The research population was all senior high school students of class XI social group in 45 public and private high schools in Yogyakarta City. The student sample of 122 students was established by using the proportional random sampling area technique. The data were collected by using a questionnaire for teachers' competency, learning motivation, home environment, and documentation for learning achievement variable. The testing of the instrument validity was done through expert judgment and factor analysis, while the reliability testing used Alfa CronbachThe result of this study shows that: (1) teachers' competency shows significant effects on students' learning achievement with the effective contribution $\left(R^{2}\right)$ of 6.1\%; (2) learning motivation shows significant effects on students'learning achievement with the effective contribution $\left(R^{2}\right)$ of $36.8 \%$; (3) home environment shows significant effects on students'learning achievement with the effective contribution $\left(R^{2}\right)$ of $4.1 \%$; (4) teachers' competency, learning motivation,
\end{abstract}


and home environment together show positive and significant effects on students' learning achievement with the effective contribution $\left(R^{2}\right)$ of $41.4 \%$. This means that the independent variables teachers' competency, learning motivation, and home environment effects on students' learning achievement partially and together.

Keywords: teachers' competency, learning motivation, home environtment, learning achievement

\section{Pendahuluan}

Pendidikan merupakan salah satu sarana strategis bagi peningkatan mutu sumber daya manusia, selain itu pendidikan juga merupakan salah satu tolok ukur tingkat kemajuan suatu bangsa. Atas dasar itu pula, upaya untuk meningkatkan kualitas penyelenggaraan pendidikan akan senantiasa dilakukan.

Pendidikan merupakan ujung tombak pembangunan nasional, karena di dalamnya ada proses pembinaan untuk menciptakan sumber daya manusia (SDM) yang handal dan berkualitas. Pada saat ini keunggulan suatu bangsa tidak lagi ditandai dengan melimpahnya kekayaan alam, melainkan pada keunggulan Sumber Daya Manusia (SDM).

Mutu Sember Daya Manusia (SDM) berkorelasi positif dengan mutu pendidikan. Pendidikan yang bermutu sangat membutuhkan tenaga pendidik yang kompeten. Oleh karena itu, tenaga pendidik harus kompeten dalam melaksanakan tugasnya secara professional sehingga menghasilkan lulusan yang lebih bermutu, berakhlak mulia, sehat, berilmu, cakap, kreatif, dan mandiri. Parameter yang digunakan untuk mengukur tingkat keberhasilan pendidikan adalah hasil belajar siswa.

Untuk mencapai hasil belajar yang optimal, guru merupakan salah satu faktor penentu berhasil tidaknya suatu pembelajaran. Keberhasilan penyelenggaraan pembelajaran sangat ditentukan oleh kesiapan guru dalam mengelola pembelajaran. Oleh karena itu, guru harus menciptakan pembelajaran yang kreatif dan menyenangkan. Untuk itu guru harus memiliki ketrampilan mengelola pembelajaran.

Dalam kaitannya dengan keterampilan pembelajaran Mulyasa (2010, p.69), berpendapat bahwa "keterampilan mengajar merupakan kompetensi professional yang cukup kompleks, sebagai integrasi dari berbagai kompetensi guru secara untuh dan menyeluruh". Guru sebagai penyelenggara pendidikan merupakan komponen utama yang harus memiliki sejumlah kompetensi handal yang mampu melahirkan anak didik yang memiliki kecakapan hidup baik secara general maupun specific (general life skills dan specific life skills). Akan tetapi, berdasarkan data hasil uji kompetensi awal (UKA) guru tingkat SMA tahun 2012 dari tiga puluh tiga provinsi, hanya 10 provinsi yang mencapai standar ratarata nasional, sedangkan 23 Provinsi di bawah standar rata-rata nasional. Hasil UKA tahun 2012 yang dilaksanakan oleh tim Direktorat Tenaga Kependidikan bekerjasama dengan Pusat Kurikulum, PGRI, dan LPTK disajikan dalam tabel 1 berikut ini.

Tabel 1. Hasil uji kompetensi guru tahun 2012

\begin{tabular}{lcc}
\hline Provinsi & Rerata & Rata-rata Nasional \\
\hline Bali & 59,03 & \\
Jateng & 56,90 & \\
Jakarta & 56,22 & \\
DIY & 55,43 & \\
Jabar & 55,35 & \\
Jatim & 54,36 & \\
Kepri & 53,81 & \\
Sum.barat & 53,54 & \\
Banten & 52,59 & \\
Kalbar & 51,55 & 51,35 \\
Kaltim & 50,91 & \\
Riau & 50,82 & \\
Bangka & 50,64 \\
NTB & 50,43 \\
Kalsel & 50,18 \\
Lampung & 49,64 \\
Gorontalo & 49,43 \\
Bengkulu & 48,96 \\
Sumut & 48,76
\end{tabular}


Tabel 1. Lanjutan

\begin{tabular}{lll}
\hline Provinsi & Rerata & Rata-rata Nasional \\
Kalteng & 48,47 & \\
Sumsel & 48,28 & \\
NTT & 48,04 & \\
Sulsel & 48,00 & \\
Papua & 47,88 & \\
Sultengg & 47,46 & \\
Sulut & 46,06 & \\
Sulteng & 46,01 & 51,35 \\
Sulbar & 45,09 & \\
Jambi & 44,86 & \\
P.Barat & 44,57 & \\
Maluku & 43,79 \\
Aceh & 43,72 \\
Malutar & 40,31 & \\
\hline
\end{tabular}

Dengan demikian, dari data tersebut kompetensi guru masih dikategorikan rendah. Padahal pemerintah dan para pakar pendidikan telah merancang uji kompetensi tersebut sedemikian rupa dalam rangka peningkatan mutu pendidikan.

Muliasya (2012, p.10) mengatakan faktor yang menyebabkan rendahnya kompetensi profesional guru antara lain; (1) masih banyak guru yang tidak menekuni profesinya secara utuh. Hal ini disebabkan oleh sebagian guru yang bekerja di luar jam kerjanya untuk memenuhi kebutuhan hidup sehari-hari, sehingga waktu belajar untuk meningkatkan kompetensi diri tidak memadai; (2) belum adanya standar profesional guru sebagaimana tuntutan di negara-negara maju; (3) kemungkinan disebabkan oleh adanya perguruan tinggi abal-abal sebagai pencetak guru yang lulusannya asal jadi tanpa memperhitungkan outputnya kelak di lapangan; (4) kurangnya motivasi guru dalam meningkatkan kualitas diri, padahal guru memiliki andil yang sangat besar terhadap keberhasilan pembelajaran di sekolah.

Dari beberapa faktor tersebut, dalam kegiatan proses pembelajaran di sekolah, guru menempati kedudukan yang sangat penting. Studi yang dilakukan Heyneman \& Loxley pada tahun 1983 di 29 negara menemukan bahwa di antara berbagai masukan (input) yang menentukan mutu pendidikan (yang ditunjukkan oleh prestasi belajar siswa) sepertiganya ditentukan oleh guru. Peranan guru makin penting lagi di tengah keterbatasan sarana dan prasarana sebagaimana dialami oleh negara-negara sedang berkembang. Hasil studi di 16 negara sedang berkembang menunjukkan, bahwa guru memberi kontribusi terhadap prestasi belajar sebesar 34\%; sedangkan manajemen $22 \%$; waktu belajar $18 \%$; dan sarana fisik 26\% (Widoyoko, 2005, p.369). Sedangkan di 13 negara industri, kontribusi guru adalah $36 \%$; manajemen $23 \%$; waktu belajar 22\%; dan sarana fisik 19\% (Widoyoko \& Anita Rinawati, 2012, p.279).

Selain kompetensi guru, motivasi belajar siswa juga berperan penting dalam pencapaian hasil belajar. Motivasi merupakan suatu kondisi yang menggerakkan peserta didik agar mampu mencapai tujuan dari motifnya (Wibowo \& Marzuki, 2015, p.161). Motivasi adalah proses rangsangan dan membangkitkan perilaku seseorang, memberikan arahan untuk perilaku dan mempertahankan perilaku yang kuat. Dalam hal belajar, siswa akan berhasil kalau dalam dirinya sendiri ada kemauan, keinginan, dan dorongan untuk belajar, karena dengan motivasi belajar maka siswa akan tergerak, terarahkan sikap dan perilaku dalam belajar. Dalam kaitannya dengan motivasi Mulyasa (2010, p.174) mengatakan "motivasi merupakan salah satu faktor yang dapat meningkatkan kulitas pembelajaran, karena peserta didik akan belajar dengan sungguhsungguh apabila memiliki motivasi yang tinggi". Dengan motivasi akan tumbuh dorongan untuk melakukan sesuatu dalam kaitannya dengan pencapaian tujuan pembelajaran.

Senada dengan pernyataan di atas Ting Lin \& Min Jou (2013,p.157), menyatakan "enhancing student learning motivation is important for the teaching and learning of new knowledge or skills because motivation would affect how instructors and students interact with learning materials". Meningkatkan motivasi belajar siswa adalah penting untuk proses pembelajaran karena motivasi akan mempengaruhi bagaimana guru dan siswa berinteraksi dengan materi pembelajaran. Oleh karena itu, untuk meningkatkan kulitas pembelajaran, guru harus dapat memotivasi siswa agar lebih giat belajar.

Hal tersebut dari 122 siswa yang dijadikan sampel, 4,9\% menyatakan bahwa faktor yang menyebabkan siswa bosan atau tidak ada semangat belajar antara lain; (1) siswa menganggap pelajaran tersebut sulit, (2) kepenatan atas gaya/ 
sistem belajar yang diterapkan monoton, (3) fasilitas/prasarana pembelajaran yang kurang memadai. Dalam hal ini terbukti dari hasil try out tahap 2 tahun 2013, motivasi siswa masih rendah sehingga mengakibatkan hasil belajar siswa juga rendah, khususnya hasil belajar siswa SMA di Kota Yogyakarta sebagaimana disajikan pada tabel 2 berikut ini.

Tabel 2 Hasil Tryout UN Tahap 2 Tahun 2012

\begin{tabular}{|c|c|c|c|}
\hline Mapel & Tertinggi & Terendah & Rerata \\
\hline Sosio & 8.86 & 3.00 & 6.58 \\
\hline B.Indo & 7.05 & 3.63 & 5.59 \\
\hline B.Ingg & 8.12 & 2.57 & 5.29 \\
\hline Eko & 8.79 & 1.50 & 4.50 \\
\hline Mat & 8.78 & 1.50 & 4.49 \\
\hline Geo & 6.74 & 2.00 & 4.30 \\
\hline
\end{tabular}

Dari data tabel 2 tersebut, nilai rata-rata hasil try out siswa pada mata pelajaran ekonomi masih dikategorikan rendah, bila dibandingkan dengan Bahasa Indonesia, Bahasa Inggris, dan Sosiologi. Inilah yang menjadi permasalahan pembelajaran yang dihadapi guru, siswa, bahkan orang tua siswa. Hal tersebut bermula dari siswa yang cenderung pasif belajar, motivasi belajarnya kurang, sehingga mengakibatkan hasil belajar yang diperoleh rendah.

Selain itu juga, 3,28\% hasil survei awal di lapangan, faktor yang mempengaruhi rendahnya nilai siswa adalah kurangnya partisipasi dari keluarga (orang tua). Djamarah (2011, p.241) mengatakan keluarga adalah lembaga pendidikan informal (luar sekolah) yang diakui keberadaannya dalam dunia pendidikan. Karena keluarga merupakan tempat dimana siswa melakukan sosialisasi pertama kalinya dan lingkungan pertama dalam pembentukan kepribadian, kemampuan, tuntunan, dan contohcontoh yang baik bagi anak. Di dalam lingkungan keluargalah anak mendapatkan perhatian, kasih sayang, dorongan, bimbingan, keteladanan, dan pemenuhan kebutuhan ekonomi, sehingga anak dapat mengembangkan segala potensi yang dimilikinya demi meraih hasil belajar yang maksimal.

Sementara itu, berdasarkan hasil penelitian yang dilakukan oleh Hasanah (2014, p.4), salah satu penyebab hasil belajar siswa rendah adalah karena masalah dalam lingkungan keluarga siswa di antaranya: 1) kurangnya waktu keluarga membimbing anak dalam belajar; 2) keluarga belum menyiapkan fasilitas belajar yang memadai; dan 3) keluarga selalu beranggapan bahwa kegiatan belajar di sekolah sudah cukup untuk memenuhi pendidikan anaknya. Padahal, Gunarsa (2009, p.5) mengatakan bahwa lingkungan keluarga merupakan lingkungan pertama yang mula-mula memberikan pengaruh yang mendalam bagi anak. Hal ini relevan dengan pendapat Slameto (2010, p.60), siswa yang belajar akan menerima pengaruh dari keluarga berupa: cara orang tua mendidik, relasi antara angota keluarga, suasana rumah tangga, dan keadaan ekonomi keluarga. Hal itu juga relevan dengah hasil penelitian yang dilakukan oleh Tirtiana (2013. p.20), yang menyatakan bahwa lingkungan keluarga memiliki pengaruh langsung dan tidak langsung terhadap hasil belajar 0,342 atau dalam persentase $34,2 \%$. Oleh sebab itu, dukungan keluarga sangat berpengaruh terhadap hasil belajar siswa.

Berdasarkan latar belakang tersebut, perlu dilakukan penelitian terkait dengan kompetensi guru, motivasi belajar, lingkungan keluarga, dan hasil belajar Siswa pada Mata Pelajaran Ekonomi di SMA Kota Yogyakarta.

Tujuan yang ingin dicapai dalam penelitian ini adalah untuk mengetahui; (1) pengaruh kompetensi guru terhadap hasil belajar siswa; (2) pengaruh motivasi belajar terhadap hasil belajar siswa; (3) pengaruh lingkungan keluarga terhadap hasil belajar siswa; dan (4) pengaruh kompetensi guru, motivasi belajar dan lingkungan keluarga secara bersama-sama terhadap hasil belajar siswa pada mata pelajaran ekonomi kelas XI di SMA Kota Yogyakarta.

\section{Metode Penelitian}

Sesuai dengan permasalahannya, penelitian ini merupakan penelitian asosiatif kausal dengan pendekatan kuantitatif (Juliandi. dkk, 2014, p.14). Penelitian kuantitatif berlandaskan pada filsafat positivisme yang memandang suatu fenomena dapat diklasifikasikan, relative tetap, konkrit, teramati,terukur, dan hubungan gejala bersifat sebab akibat (Sugiyono, 2010, p.8). Data kuantitatif tersebut diwujudkan dalam bentuk angka-angka, kemudian diolah menggunakan analisis statistik. 
Populasi penelitian ini adalah semua siswa kelas XI IPS di 45 SMA negeri dan swasta di Kota Yogyakarta. Sampel sekolah diambil sejumlah lima sekolah dengan teknik area random sampling. Sampel siswa sebanyak 122 siswa ditentukan dengan teknik area proporsional random sampling. Pengumpulan data menggunakan angket untuk variabel kompetensi guru, motivasi belajar, dan lingkungan keluarga, serta dokumentasi untuk variabel hasil belajar. Pengujian validitas instrumen dilakukan dengan expert judgment dan analisis factor, sedangkan uji reliabilitas menggunakan Alfa Cronbach. Analisis data menggunakan teknik regresi linier sederhana dan ganda.

\section{Hasil Penelitan dan Pembahasan}

\section{Hasil}

\section{Uji Persyaratan}

Uji normalitas data dalam penelitian ini menggunakan uji Kolmogorov Smirnov. Ketentuan pengambilan keputusan uji normalitas data dapat berpedoman pada kriteria, jika nilai asymp. Sig $>0,05$, maka model regresi memenuhi asumsi normal, tetapi sebaliknya jika nilai nilai asymp. Sig $<0,05$, maka tidak berdistribusi normal (Ghozali, 2011, p.165). Dan uji normalitas menunjukkan bahwa hasil belajar siswa memiliki nilai asymp.sig (p) sebesar 0.883, kompetensi guru memiliki nilai asymp.sig (p) sebesar 0.083 , motivasi belajar memiliki nilai asymp.sig (p) sebesar 0.109, dan lingkungan keluarga memiliki nilai asymp.sig (p) sebesar 0.105. Dengan demikian dapat disimpulkan bahwa data kompetensi guru, motivasi belajar, dan lingkungan keluarga terhadap hasil belajar siswa berdistribusi normal. Sementara itu, hasil uji linieritas juga menunjukkan bahwa semua variabel memenuhi persyaratan yaitu semuan nilai Deviation from Linierity $>0,05$, dan uji multikolinieritas menunjukkan bahwa semua variabel juga memenuhi persyaratan yang baik dilihat dari semua nilai VIF variabel lebih kecil dari 10.

\section{Pembahasan}

Secara keseluruhan hasil uji hipotesis dalam penelitian ini dapat disajikan dalam pembahasan sebagai berikut.
Pengaruh kompetensi guru terhadap hasil belajar siswa pada mata pelajaran ekonomi di SMA Kota Yogyakarta

Berdasarkan data statistik dapat dideskripsikan bahwa variabel kompetensi guru $\left(\mathrm{X}_{1}\right)$ dari 122 siswa yang menjadi sampel, $28,7 \%$ atau 35 siswa memiliki persepsi tentang kompetensi guru tinggi, 54,9\% atau 67 siswa memiliki persepsi tentang kompetensi guru sedang, dan $16,4 \%$ atau 20 siswa memiliki persepsi tentang kompetensi guru rendah. Hal ini menunjukkan bahwa kompetensi guru memberikan kontribusi positif terhadap hasil belajar siswa.

Hasil uji hipotesis menunjukkan bahwa kompetensi guru berpengaruh positif dan signifikan terhadap hasil belajar sisawa secara parsial dengan koefisien beta 0,113 artinya jika variabel independen lain nilainya tetap dan kompetensi guru mengalami kenaikan 1\%, maka nilai hasil belajar siswa (Y) akan mengalami peningkatan sebesar 0,113 . Koefisien bernilai positif artinya terjadi hubungan yang searah antara kompetensi guru dengan hasil belajar siswa, semakin tinggi nilai koefisien regresi kompetensi guru, maka semakin tinggi pula nilai hasil belajar siswa. Sementara koefisien diterminasi atau besarnya sumbangan pengaruh kompetensi guru $\left(\mathrm{X}_{1}\right)$ terhadap hasil belajar siswa $(\mathrm{Y})$ adalah 0,078 atau $7,8 \%$. Dengan demikian, dapat disimpulkan bahwa guru memberikan kontribusi terhadap hasil belajar siswa. Oleh karena itu, guru selaku penyelenggara pendidikan harus senantiasa mengembangkan diri secara mandiri serta tidak bergantung pada inisiatif kepala sekolah dan supervisor, sehingga mampu melahirkan anak didik yang memiliki kecakapan hidup baik secara general maupun specific (general life skills dan specific life skills. Dalam hal ini, guru harus mampu melaksanakan tugasnya dengan baik. Mulyasa (2010, p.37) mengatakan setidaknya ada 15 peran guru di antaranya; 1) guru sebagai pendidik; 2) guru sebagai pengajar; 3) guru sebagai pembimbing; 4) guru sebagai pelatih; 5) guru sebagai penasehat; 6) guru sebagai pembaharu (inovator); 7) guru sebagai model/ teladan; 8) guru sebagai pribadi; 9) guru sebagai peneliti; 10) guru sebagai pendorong kreatifitas; 11) guru sebagai pembangkit pandangan; 12) guru sebagai pekerja rutin; 13) guru sebagai pembawa cerita; 14) guru sebagai actor; dan 15) guru sebagai evaluator. 
Dalam hal ini dikuatkan oleh hasil penelitian Ridaul Inayah, Trisno Martono, dan Hery Sawiji (2013, p.6) menunjukkan bahwa $40,9 \%$ prestasi belajar siswa dipengaruhi oleh kompetensi guru. Hai itu juga dikuatkan oleh hasil penelitian yang dilakukan oleh Sudjana (2002) menunjukkan bahwa $76,6 \%$ hasil belajar siswa dipengaruhi oleh kinerja guru, dengan rincian: kemampuan guru mengajar memberikan sumbangan $32,43 \%$; penguasaan materi pelajaran memberikan sumbangan $32,38 \%$; dan sikap guru terhadap mata pelajaran memberikan sumbangan 8,60\% (Widoyoko \& Anita Rinawati, 2012, p.279). Hasil penelitian tersebut, guru merupakan faktor utama dalam proses pendidikan. Meskipun fasilitas pendidikannya lengkap dan canggih, namun bila tidak ditunjang oleh keberadaan guru yang berkualitas, mustahil akan menimbulkan proses belajar dan pembelajaran yang maksimal.

Dalam hal ini dikuatkan oleh hasil penelitian Sulistyowati, dkk (2012, p.1) menunjukkan bahwa secara parsial kompetensi guru berpengaruh positif dan signifikan terhadap prestasi belajar dengan kontribusi pengaruh terhadap prestasi belajar sebesar $28,40 \%$. Hal ini menunjukkan bahwa semakin baik kompetensi guru maka semakin tinggi juga prestasi belajar ekonomi.

Oleh sebab itu, setiap subkompetensi tersebut memiliki indikator esensial yang harus dikuasai oleh guru di antaranya; (a) menguasai substansi keilmuan yang terkait dengan bidang studi dan memahami materi ajar yang ada dalam kurikulum sekolah, memahami struktur, konsep dan metode keilmuan yang menaungi atau koheren dengan materi ajar, memahami hubungan konsep antar mata pelajaran terkait, dan menerapkan konsep-konsep keilmuan dalam kehidupan sehari-hari; (b) menguasai struktur dan metode keilmuan, menguasai langkahlangkah penelitian dan kajian kritis untuk memperdalam pengetahuan/materi bidang studi; (c) pengenalan peserta didik secara mendalam; (d) penguasaan bidang studi baik disiplin ilmu (disciplinary content) maupun bahan ajar dalam kurikulum sekolah; (e) penyelenggaraan pembelajaran yang mendidik yang meliputi perencanaan dan pelaksanaan pembelajaran, evaluasi proses dan hasil belajar, serta tindak lanjut untuk perbaikan dan pengayaan; dan (f) pengembangan kepribadian dan profesionalitas secara berkelanjutan sehingga guru yang memiliki kompetensi akan dapat melaksanakan tugasnya secara professional. Akan tetapi, pekerjaan ini tidak bias dilakukan oleh orang yang tidak memiliki keahlian untuk melakukan kegiatan atau pekerjaan sebagai guru. Untuk menjadi seorang guru diperlukan syarat-syarat khusus, apalagi sebagai guru yang profesional harus menguasai betul seluk-beluk pendidikan dan pengajaran dengan berbagai ilmu pengetahuan yang perlu dibina dan dikembangkan melalui masa pendidikan tertentu. Komponen yang berkaitan dengan masalah pembelajaran diantaranya adalah penguasaan materi ajar, pengelolaan program belajar-mengajar maupun pengelolaan kelas. Dalam proses belajar-mengajar, yang pertama kali dilakukan adalah menyusun Rencana Pelaksanaan Pembelajaran yang di dalamnya terdapat kegiatan merumuskan tujuan pembelajaran yang akan dicapai, langkah berikutnya ialah menentukan materi pelajaran sesuai dengan tujuan tersebut. Selanjutnya menentukan metode mengajar apa yang dapat melibatkan siswa secara aktif, kemudian menentukan alat peraga pengajaran yang dapat digunakan untuk memperjelas dan mempermudah penerimaan materi pelajaran oleh siswa serta dapat menunjang tercapainya tujuan tersebut. Langkah terakhir adalah menentukan alat evaluasi yang dapat mengukur tercapai tidaknya tujuan yang hasilnya dapat dijadikan pedoman guru dalam meningkatkan kualitas mengajarnya.

Meskipun guru secara sungguh-sungguh telah berupaya merancang dan melaksanakan kegiatan pembelajaran dengan baik, namun masalah-masalah belajar tetap akan dijumpai guru. Hal ini merupakan kegiatan yang dinamis sehingga guru perlu secara terus menerus mencermati perubahan-perubahan yang terjadi pada siswa di kelas. Harapan yang tidak pernah sirna dan selalu guru tuntut adalah bagaimana bahan pelajaran yang disampaikan guru dapat dikuasai anak didik secara tuntas. Ini merupakan masalah yang cukup sulit yang dirasakan oleh guru. Kesulitan itu dikarenakan anak didik bukan hanya sebagai individu dengan segala keunikannya, tetapi mereka juga sebagai makhluk sosial dengan latar belakang yang berbeda sehingga kompetensi yang paling utama dimiliki oleh guru dalam pembelajran adalah kompetensi pedagogik dan profesional.

Bottom of FormSenada dengan pendapat Priansa (2014, p.124), "Kemampuan yang perlu 
dimiliki guru berkenaan dengan kompetensi pedagogik adalah; 1) Penguasaan terhadap teori belajar dan prinsip-prinsip pembelajaran yang mendidik; 2) Mampu mengembangkan kurikulum yang terkait dengan bidang pengembangan yang diampu; 3) Memanfaatkan teknologi informasi dan komunikasi untuk kepentingan penyelenggaraan kegiatan pengembangan yang mendidik; 4) Melakukan penilaian dan evaluasi proses hasil belajar, memanfaatkan hasil penilaian dan evaluasi untuk kepentingan pembelajaran; dan 5) Melakukan tindakan reflektifuntuk peningkatan kualitas pembelajaran. Sedangka kriteria kompetensi yang melekat pada kompetensi professional guru meliputi: 1) Menguasai materi, struktur, konsep dan pola pikir keilmuan yang mendukung mata pelajaran yang diampu; 2) Menguasai standar kompetensi dan kompetensi dasar mata pelajaran yang diampu; 3) Mengembangkan materi pelajaran yang diampu secara kreatif; 4) Memanfaatkan teknologi informasi dan komunikasi untuk berkomunikasi dan mengembangkan diri”.

Pada penelitian ini pengaruh kompetensi guru terhadap hasil belajar siswa sebesar $7,8 \%$, hal ini kontribusi guru masih rendah. Rendahnya kompetensi guru dikuatkan oleh teori Mulyasa (2012, p.10) mengatakan faktor yang menyebabkan rendahnya profesional guru antara lain; (1) masih banyak guru yang tidak menekuni profesinya secara utuh. Hal ini disebabkan oleh sebagian guru bekerja di luar jam kerjanya untuk memenuhi kebutuhan hidup sehari-hari, sehingga waktu belajar untuk meningkatkan kompetensi diri tidak memadai; (2) belum adanya standar profesional guru sebagaimana tuntutan di negaranegara maju; (3) kemungkinan disebabkan oleh adanya perguruan tinggi abal-abal sebagai pencetak guru yang lulusannya asal jadi tanpa memperhitungkan outputnya kelak di lapangan; (4) kurangnya motivasi guru dalam meningkatkan kualitas diri, padahal guru memiliki andil yang sangat besar terhadap keberhasilan pembelajaran di sekolah. Padahal hasil tudi yang dilakukan Heyneman \& Loxley di 16 negara sedang berkembang menunjukkan, bahwa guru memberi kontribusi terhadap prestasi belajar sebesar 34\%; sedangkan manajemen $22 \%$; waktu belajar $18 \%$; dan sarana fisik 26\% (Widoyoko, 2005:369).
Pengaruh motivasi belajar terhadap hasil belajar siswa pada mata pelajaran ekonomi di SMA Kota Yogyakarta

Berdasarkan data statistik dapat dideskripsikan bahwa variabel motivasi belajar $\left(\mathrm{X}_{2}\right)$ dari 122 siswa yang menjadi sampel, $21,3 \%$ atau 26 siswa memiliki motivasi belajar kategori tinggi, $48,4 \%$ atau 59 siswa memiliki motivasi belajar kategori sedang, $30,3 \%$ atau 37 siswa memiliki motivasi belajar kategori rendah. Hal ini menunjukkan bahwa motivasi belajar memberikan kontribusi positif terhadap hasil belajar siswa.

Hasil uji hipotesis menunjukkan bahwa motivasi belajar berpengaruh positif dan signifikan terhadap hasil belajar sisawa secara parsial dengan koefisien beta 0,584 yang bernilai positif, sedangkan koefisien diterminasi atau besarnya sumbangan pengaruh motivasi belajar $\left(\mathrm{X}_{2}\right)$ terhadap hasil belajar siswa $(\mathrm{Y})$ adalah $0,36,8$ atau $36,8 \%$.

Motivasi belajar siswa dalam proses pembelajaran sangat berperan penting dalam pencapaian hasil belajar. Karena Motivasi merupakan rangsangan yang membangkitkan perilaku seseorang, memberikan arahan untuk perilaku dan mempertahankan perilaku yang kuat. Dalam hal belajar, siswa akan berhasil kalau dalam dirinya sendiri ada kemauan, keinginan, dan dorongan untuk belajar, karena dengan motivasi belajar maka siswa akan tergerak, terarahkan sikap dan perilaku dalam belajar. Dalam kaitannya dengan motivasi Mulyasa (2010, p.174) mengatakan "motivasi merupakan salah satu faktor yang dapat meningkatkan kulitas pembelajaran, karena peserta didik akan belajar dengan sungguh-sungguh apabila memiliki motivasi yang tinggi”. Dengan motivasi akan tumbuh dorongan untuk melakukan sesuatu dalam kaitannya dengan pencapaian tujuan dari pembelajaran tersebut. Senada dengan pernyataan Ting Lin \& Min Jou (2013, p.157), meningkatkan motivasi belajar siswa adalah penting untuk proses belajar mengajar pengetahuan atau keterampilan baru karena motivasi akan mempengaruhi bagaimana guru dan siswa berinteraksi dengan materi pembelajaran.

Pada penelitian ini pengaruh motivasi belajar terhadap hasil belajar siswa sebesar $36,8 \%$. Persentase ini cukup, karena peneliti melihat motivasi dan keinginan dari para siswa 
untuk berhasil sangat tinggi, sehingga motivasi belajar dapat memberikan pengaruh terhadap hasil belajar mereka. Koefisien bernilai positif artinya terjadi hubungan yang searah antara motivasi belajar dengan hasil belajar siswa, semakin tinggi nilai koefisien motivasi belajar maka semakin tinggi pula nilai hasil belajar siswa. Hal ini relevan dengan penelitian Inayah, Martono, dan Sawiji (2012, p.9) yang menyatakan motivasi belajar memberikan pengaruh langsung terhadap prestasi belajar siswa pada mata pelajaran ekonomi sebesar 0,393 atau 39,9\%. Dengan demikian, dapat disimpulkan bahwa siswa yang mempunyai motivasi belajar yang tinggi akan mempunyai minat dan semangat yang tingggi dalam belajar, sehingga siswa yang memiliki motivasi belajar yang tinggi akan belajar dengan senang dan sukarela. Sebaliknya siswa yang tingkat motivasinya rendah akan mempunya minat dan semangat yang rendah pula dalam belajar dan malas untuk mengikuti proses pembelajaran. Demikian pula dalam pembelajaran ekonomi, siswa yang memiliki motivasi belajar yang tinggi akan mengikuti proses pembelajaran dengan hati yang senang, bersungguh-sungguh dalam memperhatikan pelajaran, dan dengan sukarela mengerjakan tugas yang diberikan oleh guru. Dengan berbekal semangat dan kesenangan hati tersebut, maka akan berdampak pada perolehan hasil belajar mata pelajaran ekonomi yang tinggi. Sebaliknya siswa yang memiliki motivasi yang rendah akan mempunyai minat dan semangat yang rendah dalam belajar. Mereka akan cendrung kurang memperhatikan pelajaran, dan malas mengerjakan tugas yang diberikan oleh guru, sehingga hasil belajar yang diperoleh pada mata pelajaran ekonomi akan rendah.

Pengaruh lingkungan keluarga terhadap hasil belajar siswa pada mata pelajaran ekonomi di SMA Kota Yogyakarta

Berdasarkan data statistik dapat dideskripsikan bahwa variabel lingkungan keluarga $\left(\mathrm{X}_{3}\right)$ dari 122 siswa yang menjadi sampel, 30,3\% atau 37 siswa memiliki lingkungan keluarga kategori tinggi, $47,5 \%$ atau 58 siswa memiliki lingkungan keluarga kategori sedang, $22,1 \%$ atau 27 siswa memiliki lingkungan keluarga kategori rendah. Hal ini menunjukkan bahwa lingkungan keluarga memberikan kontribusi positif terhadap hasil belajar siswa.
Hasil uji hipotesis menunjukkan bahwa lingkungan keluarga berpengaruh signifikan terhadap hasil belajar sisawa secara parsial dengan koefisien beta 0,183 yang bernilai positif, sedangkan koefisien diterminasi atau besarnya sumbangan pengaruh kompetensi guru $\left(\mathrm{X}_{1}\right)$ terhadap hasil belajar Siswa (Y) adalah 0,041 atau $4,1 \%$.

Pada penelitian ini pengaruh lingkungan keluarga terhadap hasil belajar siswa sebesar 4,1\%. Persentase ini kecil, karena 3,28\% hasil survei awal di lapangan yang mempengaruhi rendahnya nilai siswa adalah kurangnya partisipasi dari keluarga (orang tua). Hal tersebut relevan dengan hasil penelitian Hasanah (2014, p.4) salah satu penyebab hasil belajar siswa rendah karena masalah dalam lingkungan keluarga siswa di antaranya; (1) kurangnya waktu keluarga membimbing anak dalam belajar; (2) keluarga belum menyiapkan fasilitas belajar yang memadai; dan (3) keluarga selalu beranggapan bahwa kegiatan belajar di sekolah sudah cukup untuk memenuhi pendidikan anaknya; dan (4) Orang tua siswa terlalu sibuk dengan pekerjaannya yang menyebabkan kurangnya perhatian yang mereka berikan dan cenderung tidak acuh terhadap kegiatan belajar anak. Siswa yang dididik dan dibimbing dalam keluarga yang kurang kasih sayang dan kurang perhatian, maka siswa tersebut akan tumbuh dan berkembang menjadi anak yang nakal dan pemalas. Oleh sebab itu, dukungan keluarga sangat penting dan berpengaruh terhadap hasil belajar siswa.

Koefisien bernilai positif artinya terjadi hubungan yang searah antara lingkungan keluarga dengan hasil belajar siswa, semakin tinggi nilai koefisien lingkungan keluarga, maka semakin tinggi pula nilai hasil belajar siswa. Dalam hal ini sesuai dengan pendapat Djamarah (2011, p.241) "keluarga adalah lembaga pendidikan informal (luar sekolah) yang diakui keberadaannya dalam dunia pendidikan". Peranannya tidak kalah penting dari lembaga formal dan non formal. Bahkan sebelum anak didik memasuki sekolah, dia sudah mendapatkan pendidikan dalam keluarga yang bersifat kodrati. Hubungan darah antara kedua orang tua dengan anak menjadikan keluarga sebagai lembaga pendidikan yang alami. Sehingga faktor lingkungan keluarga sangat mempengaruhi hasil belajar siswa. Lingkungan keluarga banyak mempengaruhi kegiatan belajar siswa, karena keluarga merupakan tempat 
dimana siswa melakukan sosialisasi untuk yang pertama kalinya dan lingkungan pertama dalam pembentukan kepribadian kemampuan anak.

Oleh karena itu, partisipasi dukungan keluarga sangat penting bagi siswa dan sudah seharusnya orang tua untuk mendukung pendidikan anak terus-menerus sehingga hasil belajar yang diperoleh anak akan lebih baik dan optimal, meski beberapa siswa tidak lagi merasakan kehadiran orang tuanya di sekolah ataupun di rumah, karena orang tuannya sudah meninggal, sehingga hanya bersama kerabat bahkan ada siswa yang tidak pernah tahu keberadaan orang tuanya. Oleh karena itu, keterlibatan orang tua juga sangat mendukung keberhasilan anak dalam meraih prestasi ataupun hasil belajar. Dalam hal ini senada denga teori yang dikemukakan oleh Gunarsa (2009, p.5) mengatakan bahwa lingkungan keluarga merupakan "lingkungan pertama yang mulamula memberikan pengaruh yang mendalam bagi anak". Peran orang tua yang seharusnya adalah sebagai orang pertama dalam meletakkan dasardasar pendidikan terhadap anak-anaknya. Dengan hal tersebut, kehidupan keluarga terutama peran orang tua merupakan lingkungan pendidikan pertama yang mempunyai peranan penting dalam menentukan dan membina proses perkembangan anak. Tidak menutup kemungkinan bahwa masalah yang dialami siswa di sekolah seperti rendahnya prestasi belajar siswa dan berhasil tidaknya proses belajar siswa merupakan akibat atau lanjutan dari situasi lingkungan keluarga yang tidak harmonis dan peran orang tua yang tidak dijalankan dengan baik.

Pengaruh kompetensi guru, motivasi belajar, dan lingkungan keluarga terhadap hasil belajar siswa pada mata pelajaran ekonomi di SMA Kota Yogyakarta

Berdasarkan data statistik dapat dideskripsikan bahwa pada variabel hasil belajar (Y) dari 122 siswa yang menjadi sampel, $25,4 \%$ atau 31 siswa memiliki nilai hasil belajar kategori tinggi dan $74,6 \%$ atau 91 siswa memiliki nilai kategori sangat sedang. Hal ini menunjukkan bahwa hasil belajar siswa berkontribusi positif.

Hasil uji hipotesis menunjukkan bahwa kompetensi guru, motivasi belajar, dan lingkungan keluarga berpengaruh signifikan terhadap hasil belajar sisawa secara simultan dengan koefisien diterminasi atau besarnya sumbangan pengaruh kompetensi guru, motivasi belaja, dan lingkungan keluarga terhadap hasil belajar siswa pada mata pelajaran ekonomi di SMA Kota Yogyakarta sebesar 0,431 atau 43,1\%. Dan dari hasil uji $\mathrm{F}$ pada taraf signifikan 5\% diketahui nilai probabilitas (p) $0,000<0,05$ yang ditunjukkan pada kolom signifikansi.

Pada penelitian ini pengaruh kompetensi guru, motivasi belajar, dan lingkungan keluarga terhadap hasil belajar siswa pada mata pelajaran ekonomi sebesar 0,431 atau $43,1 \%$ dan sisanya $56,9 \%$ dijelaskan oleh faktor lain di luar model yang diteliti. Hasil penelitian menunjukkan bahwa kompetensi guru, motivasi belajar, dan lingkungan keluarga yang tinggi, maka hasil belajar siswa juga akan meningkat, dan begitu juga sebaliknya apabila kompetensi guru, motivasi belajar, dan lingkungan keluarga rendah maka hasil belajar siswa pun menurun.

Hal ini relevan dengan penelitian Inayah, Martono, dan Sawiji (2012, p.9) yang menyatakan kompetensi guru dan motivasi belajar berpengaruh positif terhadap prestasi atau hasil belajar siswa. Sedangkan Hasil penelitian yang dilakukan oleh Sudjana (2002) menunjukkan bahwa $76,6 \%$ hasil belajar siswa dipengaruhi oleh kinerja guru, dengan rincian: kemampuan guru mengajar memberikan sumbangan 32,43\%; penguasaan materi pelajaran memberikan sumbangan $32,38 \%$; dan sikap guru terhadap mata pelajaran memberikan sumbangan $8,60 \%$ (Widoyoko \& Anita Rinawati, 2012, p.279).

Selain kompetensi guru, motivasi belajar siswa juga berperan penting dalam pencapaian hasil belajar. Oleh karena itu, untuk meningkatkan kulitas pembelajaran, guru harus dapat memotivasi siswa untuk lebih giat belajar. Hal tersebut akan menambah pemahaman dan wawasan siswa, sehingga memungkinkan proses pembelajaran berlangsung lebih efektif dan optimal. Motivasi belajar pada diri siswa perlu diperkuat terus menerus, dengan tujuan agar siswa memiliki motivasi belajar yang kuat, sehingga hasil belajar yang diraihnyapun dapat optimal. Tetapi apabila siswa bosan atau tidak semangat belajar akan berdampak pada hasil belajar. Begitu juga dengan lingkungan keluarga menjadi salah satu fokus kajian antropologi pendidikan, terutama mengenai sistem pewarisan kebudayaan. Di dalam keluarga itulah suatu 
generasi dilahirkan dan dibesarkan. Mereka mendapat pelajaran pertama kali, apalagi bagi masyarakat yang belum mengenal dan menciptakan lingkungan pendidikan formal. Keluarga merupakan lingkungan pendidikan yang pertama dan utama karena manusia pertama kalinya memperoleh pendidikan di lingkungan ini sebelum mengenal lingkungan yang lain. Gunarsa (2009, p.5) mengatakan bahwa lingkungan keluarga merupakan lingkungan pertama yang mula-mula memberikan pengaruh yang mendalam bagi anak. Dari anggota-anggota keluarganya (ayah, ibu dan saudara-saudaranya) anak memperoleh segala kemampuan dasar, baik intelektual maupun sosial. Lingkungan keluarga merupakan lingkungan pendidikan pertama dan utama bagi anak, karena dalam keluarga inilah anak pertama-tama mendapat didikan dan bimbingan. Dan dikatakan sebagai lingkungan yang utama karena sebagian besar dari kehidupan anak adalah di dalam keluarga. Dari lingkungan keluarga yang harmonis yang mampu memancarkan keteladanan kepada anak-anaknya, akan lahir anak-anak yang memliki kepribadian dengan pola yang mantap. Hal ini relevan dengan pendapat Slameto (2010, p.60) siswa yang belajar akan menerima pengaruh dari keluarga berupa: cara orang tua mendidik, relasi antara angota keluarga, suasana rumah tangga, dan keadaan ekonomi keluarga. Dari uraian-uraian tersebut, maka dapat disimpulkan bahwa lingkungan keluarga merupakan lingkungan pertama dan utama yang mempengaruhi perkembangan dan tingkah laku anak. Di lingkungan keluarga anak mendapatkan perhatian, kasih sayang, dorongan, bimbingan, keteladanan dan pemenuhan kebutuhan ekonomi dari orang tua sehingga anak dapat mengembangkan segala potensi yang dimilikinya demi perkembangannya di masa mendatang. Dalam hal ini relevan dengah hasil penelitian yang dilakukan oleh Tirtiana (2013, p.20), yang menyatakan bahwa lingkungan keluarga memiliki pengaruh langsung dan tidak langsung terhadap hasil belajar 0,342 atau dalam persentase $34,2 \%$.

\section{Simpulan}

Berdasarkan analisis data dan pembahasan dapat ditarik beberapa simpulan bahwa kompetensi guru berpengaruh positif dan signifikan terhadap hasil belajar siswa pada mata pelajaran ekonomi dimana nilai $\mathrm{t}_{\text {hitung }} 2,873>\mathrm{t}_{\text {tabel }}$
1,671 dan kontribusi efektif $\left(R^{2}\right)$ sebesar 0,078 atau $7,8 \%$ dengan probabilitas ( $<<0,05)$, motivasi belajar berpengaruh positif dan signifikan terhadap hasil belajar siswa pada mata pelajaran ekonomi dengan nilai $\mathrm{t}_{\text {hitung }} 8,452>\mathrm{t}_{\text {tabel }} 1,671$ dan kontribusi efektif $\left(R^{2}\right)$ sebesar 0,368 atau $36,8 \%$ dengan probabilitas $(\mathrm{p}<0,05)$, lingkungan keluarga berpengaruh positif dan signifikan terhadap hasil belajar siswa pada mata pelajaran ekonomi dengan nilai $\mathrm{t}_{\text {hitung }} 2,585>\mathrm{t}_{\text {tabel }} 1,671$ dan kontribusi efektif $\left(R^{2}\right)$ sebesar 0,041 atau 4,1\% dengan probabilitas $(\mathrm{p}<0,05)$; dan Kompetensi guru, motivasi belajar, dan lingkungan keluarga secara bersama-sama berpengaruh positif dan signifikan terhadap hasil belajar siswa pada mata pelajaran ekonomi kelas XI IPS di SMA kota Yogyakarta dengan nilai $\mathrm{F}_{\text {hitung }} 31.607>\mathrm{F}_{\text {tabel }} 2,70$ dan kontribusi efektif $\left(R^{2}\right)$ sebesar 0,431 atau $43,1 \%$ dengan probabilitas $(\mathrm{p}<0,05)$.

\section{Saran}

Berdasarkan pembahasan dan simpulan, selanjutnya dapat diajukan beberapa saran di antaranya (a) sesuai dengan hasil penelitian bahwa hasil belajar siswa pada mata pelajaran ekonomi dikategorikan tinggi, Hal tersebut menunjukkan bahwa siswa semangat dalam mengikuti pembelajaran ekonomi, sehingga nilai yang diperoleh dapat maksimal. Oleh karena itu, siswa harus mempertahankan terus hasil belajar yang telah diperoleh bila perlu harus ditingkatkan lagi dengan cara belajar sunguh-sungguh baik secara mandiri maupun berkelompok dan tidak hanya di sekolah saja melainkan di rumah; (b) kompetensi guru meberikan pengaruh yang positif dan signifikan terhadap hasil belajar siswa. Kompetensi guru berpengaruh sangat kecil bila dibandingkan dengan motivasi belajar. Dengan demikian, guru selaku faktor penentu berhasil tidaknya suatu pembelajaran harus menciptakan pembelajaran yang normatif, kreatif, dan menyenangkan. Untuk itu guru harus memiliki ketrampilan mengelola pembelajaran, karena keterampilan mengajar merupakan kompetensi professional yang cukup kompleks, sebagai integrasi dari berbagai kompetensi guru secara untuh dan menyeluruh agar mampu melahirkan anak didik yang memiliki kecakapan hidup baik secara general maupun specific (general life skills dan specific life skills); (c) motivasi belajar memberikan pengaruh yang positif dan signifikan terhadap hasil belajar siswa. Motivasi 
belajar memberikan pengaruh yang paling besar dari variabel bebas yang lainnya, akan tetapi motivasi belajar siswa perlu ditingkatkan lagi untuk memperoleh hasil belajar yang lebih baik dan maksimal. Dalam hal belajar, siswa akan berhasil kalau dalam dirinya sendiri ada kemauan, keinginan, dan dorongan untuk belajar, karena dengan motivasi belajar maka siswa akan tergerak, terarahkan sikap dan perilaku dalam belajar, karena motivasi merupakan salah satu faktor yang dapat meningkatkan kulitas pembelajaran, karena peserta didik akan belajar dengan sungguhsungguh apabila memiliki motivasi yang tinggi. Dengan motivasi akan tumbuh dorongan untuk melakukan sesuatu dalam kaitannya dengan pencapaian tujuan dari pembelajaran tersebut; (d) lingkungan keluarga memberikan pengaruh yang positif dan signifikan, akan tetapi sangat rendah. Hal tersebut disebabkan oleh; kurangnya waktu keluarga membimbing anak dalam belajar; keluarga belum menyiapkan fasilitas belajar yang memadai; keluarga selalu beranggapan bahwa kegiatan belajar di sekolah sudah cukup untuk memenuhi pendidikan anaknya; dan orang tua siswa terlalu sibuk dengan pekerjaannya yang menyebabkan kurangnya perhatian yang mereka berikan dan cenderung tidak acuh terhadap kegiatan belajar anak. Padahal dukungan keluarga sangat penting bagi anak. Oleh sebab itu, partisipasi dukungan keluarga sangat penting bagi siswa dan sudah seharusnya orang tua untuk mendukung pendidikan anaknya terus-menerus sehingga hasil belajar yang diperoleh anak akan lebih baik dan optimal. Semakin kondusif lingkungan keluarga, maka hasil belajar siswa akan semakin baik dan meningkat.

\section{Daftar Pustaka}

Djamarah, S. B. (2011). Psikologi Belajar. Jakarta: PT. Rineka Cipta.

Ghozali, H. Imam. (2011). Aplikasi Analisis Multivariate dengan Program IBM SPSS 19. Semarang: Universitas Diponegoro.

Gunarsa. (2009). Membina Keluarga Sakinah. Jakarta: PT. Pelangi Aksara.

Hasanah, B. (2014). Pengaruh Lingkungan Keluarga Terhadap Hasil Belajar Siswa Pada Mata Pelajaran Geografi di SMA Negeri 1 Marawola. E Journal GeoTadulako UNTAD.
Inayah, R., Martono, T., \& Sawiji, H. (2012). Pengaruh Kompetensi Guru terhadap Prestasi Belajar Mata Pelajaran Ekonomi pada Siswa Kelas XI IPS SMA Negeri 1 Lasem. Journal Pendidikan Insan Madani: Vol.1 No.1.

Juliandi. dkk. (2014). Metodelogi Penelitian Bisnis Konsep Aplikasi. Medan: UMSU Press.

Mulyasa, E. (2010). Menjadi Guru Profesional. Bandung: PT. Remaja Rosdakarya.

Mulyasa, E. (2012). Standar Kompetensi dan Sertifikasi Guru. Bandung: PT. Remaja Rosdakarya.

Republik Indonesia. (2012). Kementrian Pendidikan dan Kebudayaan, tentang Hasil Kompetensi Awal Guru.

Slameto. (2010). Belajar dan Faktor-Faktor Yang Mempengaruhinya. Jakarta: PT. Rineka Cipta.

Sugiyono. (2010). Statistik untuk Penelitian. Bandung: Alfabeta.

Ting Lin, Yen., \& Min Jou. (2013). Integrating Popular Web Applications In Classroom Learning Environments And Its Effects On Teaching, Student Learning Motivation And Performance. The Turkish Online Journal of Educational Technology, April 2013, volume 12 Issue 2.

Tirtiana, Chandra Putri. (2013). Pengaruh Kreativitas Belajar dan Lingkungan Keluarga terhadap Hasil Belajar di SMK Negeri 2 Blora Tahun Ajaran 2012/2013. Economic Education Analysis Journal 2 (2) (2013).

Wibowo, K.P., \& Marzuki. (2015). Penerapan Model Make A Match Berbantuan Media untuk Meningkatkan Motivasi dan Hasil Belajar IPS. Harmoni Sosial, Jurnal Pendidikan IPS, September 2015, Volume 2, No.2.

Widoyoko, S.E.P. (2005). Kompetensi Mengajar Guru Ekonomi SMA Kabupaten Purworejo. Journal Cakrawala Pendidikan, November 2005, Th. XXIV, No. 3.

Widoyoko, S.E.P., \& Anita Rinawati. (2012). Pengaruh Kinerja Guru terhadap Motivasi Belajar Siswa. Jurnal Cakrawala Pendidikan, Juni 2012,Th. XXXI, No. 2. 